\title{
Skandal jako norma w literaturze współczesnej
}

Anita Frankowiak 
napns Seria X 20()4

\section{Anita Frankowiak}

\section{Skandal jako norma w literaturze współczesnej}

Viewątpliwie literatura najnowsza (ostatnich piętnastu lat) jest terenem ogromnej eks-
pansji trendów i stylów dotychczas zaniedbywanych przez pisarzy. Jest obszarem, gdzie spotykają się idee i poglądy zupełnie ze sobą sprzeczne, gdzie toczą się dyskusje kontrowersyjne. Tak jakby teksty chciały krzyczeć, że im więcej anomalii, tym lepiej.

Swoje poszukiwania pisarze kierują w micjsca niejednoznaczne, w których albo określają własıą tożsamość, albo weryfikują prawdę o świecie zewnętrznym. To już nie tylko hermeneutyczne czy fenomenologiczne kreacje, lecz takze gnoza i ontologiczne zanyślenie.

Skandal wydaje się immanentną cechą prozy lat dziewięćdziesiątych. Terenem swym ogarnia obyczajowość, psychikę oraz relacje interpersonalne. Staje się normą, bez której bohaterowie nie potrafią żyć. W większości przypadków jest ogniwem łączącym dwie sfery ludzkiej egzystencji: dobro i zło. Tak jest w twórczości Kingi Dumin, Manueli Gretkowskiej, Nataszy Goerke, Wojciecha Kuczoka, Mariusza Maślanki, Jerzego Pilcha, Andrzeja Stasiuka, Doroty Terakowskiej i wielu innych.

Mówiąc o skandalu, mamy najczęściej na myśli to zdarzenie, które wywolato zgorszenie, oburzenie, a czasem nawet wstręt. (...) Przez skandal rozumiemy taki fakt w życiu ludzi, gdzie zakwestionowany został jakiś clement podstawowy porządku bycia spotecznego. Mamy do czynienia z naruszeniem pewnej normy spolecznej, konwencji - rozunianej jako pewna forma ludzkiego zachowania. Czyn skandaliczny pojawia się whaśnie w tym momencie, kiedy następuje zlamanie danej normy. Jest to jakby swoiste naruszenie prawa, nie zawsze explicite sformalizowanego, a często tylko niepisanego prawa obyczajowego. Możemy powiedzieć, że dramaturgia skandalu rodzi się wówczas, kiedy zostaje naruszony pewien rytuał zycia spolecznego, obyczaj właściwie, który 
jest społecznie akceptowany, powszechnie uznany jako reguła ludzkiego zachowanial.

\section{„Świat jest do dupy, więc mój stosunek do świata jest analny”2}

Gretkowska, począwszy od My zdies' e'migranty' (1992), poprzez Tarot pary'ski (1993) i Kabaret metafizy'zm)' (1994) aż do Scen z życia pozanatżenskiego, prowokuje skandalem.

Kabaret metafiz) ${ }^{\prime}=y^{\prime}$ to „dekonstrukcyjne rozbijanie stereotypów” (S. Burkot) ${ }^{3}$. Biedna Beba Mazeppo, kobieta o dwóch techtaczkach, nie znajduje zaspokojenia ani w seksie, ani w rozwiązłości obyczajowej. Jej mieszkanie, wyłożone aksamitem i dywanami, też nie daje poczucia bezpieczeństwa.

Fotografie z występów kabaretowych zawieszone w salonie powleczone zostały warstwą smutku; usta Beby przestawały się uśmiechać, niegdyś sterczące łechtaczki oklapły. Perwersja ciekną̧ca spomiędzy jej rozstawionych nóg też wydawala się być nostalgicznat.

Nostalgia i klimat destrukcji mieszal się z filozoficzno-psychologiczną próbą opisu rzeczywistości. Powodem, dla którego Gretkowska prowokuje infantylizmem i wulgarnością, jest uczucie odrzucenia i alienacji spolecznej, której doświadczają bohaterowie powieści. Łajdaczenie ,jest znane wszystkim religiom” (KM, 28). Ekshibicjonizm i masturbacja wywołtuje uczucie pojednania ze światem. Wolfgang w Lasku Bulońskim wspólzyje z motylem.

Byliśmy sobie przeznaczeni. (...) Poczulem pulsowanie jego i mojej krwi. Podałem mu ostrożnie rękę i odpiąłem spodnie. On jakby na to czekał, zaczął spacerować wzdłuż obrzmiałego jego pięknem członka. Miłośnie trzepotał skrzydłami naganiając rozkosz. (...) Wytrysnąłem w dłoń nektarem miłości, zanurzyłem w nim motyla i poczułem rozkosz jego prężącego się odwłoka, omdlewającą rozkosz zanurzenia w milości. Poczekatem aż się wypełni... Utopilem go... (KM, 81).

Ten sam wrażliwy student, poeta i niepoprawny romantyk w scenie końcowej Kabaretu odgryza Bebie lechtaczkę.

Teraz wcalowując się w Bebę nie miał wątpliwości, że dodatkowa jest ta górna, większa, która twardniejąc, rozchyla mu wargi, próbując dostać się do ust. (...)

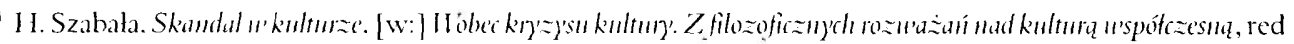
L. Grudziński. Gdańsk 1993. s.97.98.

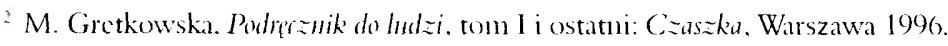

'Szcrzcj: S. Burkot. Literatura polska u' latach 1986-199.5, Kraków 1997. s. 87.

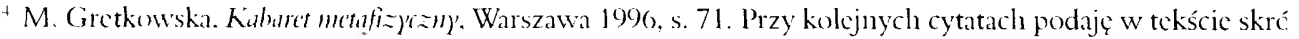
KM i numer strony. Dotyczy to takż następujących utworów: tejze, Sceny z zycia pozamał zenskicgo, Warszaw 20013 (SC); W. Kuczok. Gnojj. Warszawa 20013 (G): A. Stasiuk, Przezrzkę, Czarne 1996 (PR); M. Maślanka. Bi dul. Warszawa 2(k)+ (B).
} 
każde uderzenie stwardnialym językiem w olbrzymicjace lechtaczki wydobywało z niej jęk przypominający bełkotliwa prośbę. (...) Wolfgang gryząc Bebę. czul dreszcze jej spazmów. Jeszcze jedno mocniejsze ugryzienie, zachlyśnięcie rozkoszą i odgryziona lechtaczka potoczyla się w głąb jego gardla. Okrzyk ulgi nieprzytomnej Beby pozwolił mu zrozumieć, że była szczęśliwa, przelkıął więc odgryziony strzępek (KM, 110).

Dodatkowa techtaczka jest więc problemem nie tylko biologicznym, anomalią genetyczną, lecz przede wszystkim miejscem kunulacji lęków i negatywnych doświadczeń bohaterki skandalı. Kochanek, odgryzając kawalek mięsa, znajduje nowe wnętrze, odkrywa nową Bebę, a ona, pozbywszy się niechcianego ciała, zaczyna kochać.

Hierarchia wartości w tym tekście zostaje zupehnie zachwiana. Gretkowska profanuje ludzkie ciało. Podobnych prowokacji jest więcej. Sycylijski wujek Giugin zostawia na stole zwłoki swojej pierwszej żony i wiedzie normalne życie z drugą.

Amerykanka nie miala grama thuszczu, bardzo szybko wyschla i się rozsypała. Ninetta codziemnie ścierała kurze, ściereczka zbierała ze stolu resztki po pierwszej żonie wuja. (...) Po dwóch latach, podczas wielkich porządków wielkanocnych, Ninetta wsypała szufelkę resztek Amerykanki do worka śmieci i starla do czysta stól $(\mathrm{KM}, 70)$.

Giugiu porzuca swoją kobietę, której „dał tylko spermę”, i wiąże się Samicą. Samica to uosobienie subtelnej perwersji i obskuranctwa. Pracując u zamożnego małżeństwa, przystaje na propozycję świadczenia usług seksualnych za pieniądze. Zostawiając majtki w malżeńskiej sypiahni, prowokuje skandal obyczajowy. Ale wie, ze mogla zrobić coś gorszego:

Mogham zostawić coś bardziej intymnego, na przyklad pochwę (KM, 84) stwierdza kokieteryjnie. To idealna kobieta dla Giugiu. Jak sam wyznaje, potrzebuje wielu kobiet.

Nie można wytrzymać dhugo z jedną. Czasem nachodzi mnie pytanie, czy jeśli kocha się z kobietą tak długo, aż ona umrze, to jest to nekrofilia czy tylko roztargnienie $(\mathrm{KM}, 84)$.

Te paradoksalne ujęcia rzeczywistości mạ̣ą za zadanie przybliżý́ sferę tabu. Kim jestem? — pyta narrator. I odpowiada: Erotycznym znakiem zapytania. „Co mnie wszystko wokół obchodzi?". Co więc pozostaje? Niestety, konsumpcja i kicz.

Albo kicz, albo śmierć. Kicz jest przytulnym zakąthiem bezpieczeństwa. Wokół kiczu okrucieństwo, groza - prawdziwy obraz, dobry wiersz. Zobaczyć rzeczywistość, to zobaczyć okrucieństwo. Pokazać, co się zobaczyło, to już kicz, ale kim ja jestem? (KM, 91). 
Skandal dąży do ...maksymalnej zmiany stanu wiedzy (o czymś, kimś). Niezależnie od wartościowania i ambiwalencji pojęć, antynomia jest wyrazista: innowacja przeciw redundancji, rewelacja przeciw repetycji. I zależność odwrotnie proporcjonalna: im więcej stereotypu, tym mniej miejsca pozostaje na skandal; im coś bardziej skandalizujące, tym mulej zawiera oczywistości ${ }^{5}$.

Skandal u Gretkowskiej to perwersyjny kicz. Jednak jego okrutny wyıniar obnaża prawdę o fizjologii człowieka. Rzeczywistość jest obrzydliwa, a próba jej zrelacjonowania urasta do kategorii literackiego obskuranctwa.

Pisana książka okazuje się powieścią tworzoną wedle zachwalanej przez pojawiających się tutaj kawiarnianych idiotów i handlarzy recepty na literaturę; rzekome motywy takiego pisania, pragnienie zabawy formą i intelektem, odpadają, by na chwilę obnażyć to, co rzeczywiste: Weltschmerz, pragnienie ucieczki od tego, co się zobaczylo, od niemożności przedstawienia, ale także i zniesienia okrucienistwa rzeczywistości $i^{6}$.

Gombrowiczowskie ,koniec i bomba”...

W seksualną namiętność uwiklani są także bohaterowie Scen ż̇ycia pozannatżenskiego książki napisanej przez Gretkowską razenn z Piotrem Pietuchą. W Belladonnie (to pierwsze z opowiadań, autorstwa Gretkowskiej) skandalem obyczajowym wydaje się romans buddyjskiej mniszki, Polki Ewy Kowalskiej, i znanego malarza - Kamila Bąka. Pożądanie ujawnia się jako podniecenie, które z niecierpliwością oczekuje zaspokojenia ${ }^{7}$.

Rozetrzyj sobie przyjemność na całe ciało spomiędzy nóg - oparł się na tokciu i obserwowat jej pocieranie dlonią o lechtaczkę (SC, 163).

Cialo trzeba podporządkować, zintegrować.

Jest czymś heterogenicznym wobec czystej woli moralnej, która musi się z nim pogodzić, nie mogąc się go pozbyćs .

Nudę egzystencji może zastąpić jedynie życie nasycone popędem. By osiągnąć zaspokojenie, czlowiek wymaga zatem kogoś innego.

Sportretowany przez Piotra Pietuchę dojrzaly mężczyzna, przytłoczony rodzinnymi obowiązkami, wciąż czuje się winny. Nie radzi sobie z prostym faktem, że izoluje się od najbliż.

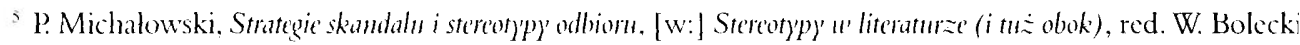
G. Gazda, Warszawa 2(0)3, s. 286.

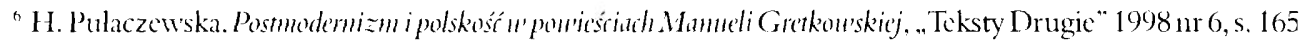

F. Chirpaz, Ciato, th. J. Migasiniski, Warszawa 1998. s. 54.

${ }^{x}$ Ibiden, s. 7 
szych. Zawozi żonę na wakacje i przeżywa romans z przypadkową autostopowiczka - Heleną. Sensem życia staje się odnalezienie jej.

Naraz stali się rozwibrowaną̧ jednością, rozjarzoną bólem i znieczuloną rozkoszą na krawędzi przytommości (...). Przytuleni calowali się, szepcząc usta w usta bezladne slowa namiętności. Szalonej i rozpasanej, triumfiującej nad nami, nimi i calym światem (SC, 288$)$.

Uklad prehistoryczny: Ich troje i demony ządz. Szaleństwo ma tragiczny final. Jerzy niszczy rodzinę, zdradza żonę i nie potrafi żyć z poczuciem winy. I Ielena odzyskıje rozsądek i ucieka. Mężczyzna pogrąża się w chaosie.

Oczywiście można przyjąć, iź przesycenie utworu takimi clementami, jak liczne sceny fizjologicznie potraktowanego seksu, tandetne opisy luksusowych gadżetów, wystroju wnętrz, prowokacyjne sentencje typu: ,zgarnął z prześcieradła grudkę zasychającego nasienia. Zrobił nią Ewie na czole znak krzyża", posługiwanie się „slownictwem genitalnym”, ze wszystko to dowodzi świadomości instrumentalnego ich potraktowania i takiego wykorzystania, dzięki któremu dochodzi do dyseminacji oraz suplementacji znaczeń rzeczywistości przedstawionej, a więc ich rozłożenia na czynniki pierwsze i ukazania innych możliwych konfiguracji sensów".

Jednakże, jaki jest cel obnażania natury czlowieka i brutalnego odzierania go ze sfery sacrunn? Podniecany się skandalem, bo nie potrafimy budować trwałych więzi międzyludzkich? Czy też tolerujemy skandal, jako nieodlączny atrybut naszej fizjologii i biologizmu? A może skandal to tylko próg naszej kottunerii?

Skandal posiada tylko dwie strony - zgorszoną i oburzoną oraz gorszącą i oburzającą. Ale jednocześnic strona pierwsza jest stroną degradującą, druga degradowaną. Która z nich wobec skandalu jest istotniejsza?"1"

Stasiuk udowadnia, że nie ma to znaczenia. Istotne jest burzenie harmonii spolecznej, ostra gra z obyczajowością. Największą szansą poznania egzystencji jest seks. Znystową hipostazą jego tajemnicy jest Nadia z tomu opowiadań Przez rzekę (1996).

Gdy Nadia pojawila się z naszym życiu — mówi narrator Podróży - ani muie, ani jemu nie przyszło do głowy pytać, skąd się wziçła i dlaczego. Przyjęliśmy jej istnienie zupetnie naturalnie (PR, 43).

Na tyle naturalnie, by utonąć w jej cielesności i wyuzdaniu bez reszty. 
W konícu zaczęliśmy się kochać. Nasze oddechy pomieszaly się, dudniły głucho, nacieraly na nas spotężniałe, twarde i nieludzkie. (...) Wykonywaliśmy szereg histerycznych, psich zwarć przerywanych krótkimi odpoczynkami. Nasza wyobraźnia próbowała przekroczyć siebie sama. Pomyślałem, że tak pierdolą się umarli, dla których jedynym wypełnieniem nieskończoności jest wyobraźnia. Stojąc, leżąc, kucając, siedząc, pełzną̧c w górę po schodach, osuwając się w dól oddawaliśmy się rzezzi, a pragnienie przybieralo postać obrzydzenia $(\mathrm{PR}, 56)$.

Bohater nie może sobie poradzić nie tylko z erotyzmem Nadii, ale i z wymykającą się opisowi pozorną bezcielesnością. Zjada jej majtki. Seksualne spełnienie zdruzgotane zostaje przez obsceniczność i wulgarność. Narrator ucieka, by nie przeżyć kolejnej klęski.

Równie skandaliczny jest kazirodczy związek Marka i Marty — bohaterów Tabu (1998) Kingi Dunin.

Gdy ich milość wyszła na jaw, a rodziny zadecydowaly o natychmiastowym rozdzieleniu młodych, próba wierności, przed którą stanęli, okazała się probierzem ich charakterów i kodeksów rodzimych: Marek, katolik, okazal się hipokrytą, który bez skrupulów poświęci milość dla wlasnego spokoju, matury, studiów i przyszłej kariery, Marta natomiast byla gotowa rzucić wszystko i skazać się na rodzinną banicję w imię uczućn'.

W Obciachu, który jest dalszym ciągiem historii dwojga, Marta uświadamia sobie, że jej kochanek to cynik i hipokryta. To nie ratuje jej jednak przed tragicznym wydarzeniem. Dochodzi do inicjacji. Mężczyzna gwalci ją i upokarza.

Powieści Kingi Dunin stawiają bardzo krytyczną diagnozę polskiej normalności: Z jednej strony widzimy kryzys dotychczasowych konwencji (patrialchalnych, polskich, katolickich etc.), z drugiej - niewydolność spolecznej komunikacji, kryzys normalnej rozmowy, brak zwyczaju dochodzenia do zgody i ustalenia wersji kompromisowych ${ }^{12}$.

Gwałt jest też przyczyną przewartościowania życia bohaterki Ono Doroty Terakowskiej. Ewa, wychowana w kołtuńskim domu, usiłuje na własną rękę nauczyć się życia. Brutalnie zgwałcona, płaci za swoją naiwność. Jej ciąża staje się skandalem rodzinnym, obyczajowym: i moralnym. A jednak bohaterka próbuje odnaleźć w życiu wartości. Zaczyna patrzeć na świa oczami plodu. To ucieczka przed zakłamaniem i piętnem wstydu. Obie młode kobiety wiedz: już, że życie po skandalı to ciagla walka o autentyczność i zachowanie godności. Gotowe for. my nie wystarczą.

"1. Czapliński, Ruchome marginesy. Szkice o literaturac lat 90. Kraków 2002, s. 137.

is lbidents. s. $1+2$. 
Jednak to przecież spoleczeństwo, grupa zawodowa, rodzina określa, jakie zachowania są negatywne.

Nie ma skandalu w sposób "obiektywny”. Chodzi zatem nie o fakt, ale o zakwalifikowanie zdarzenia, o jeggo subiektywną ocenę i rodzaj reakcji - silnie nacechowanej emocjonalnie. Nie ma skandalu dopóty, dopóki nikt jakiegoś faktu wlaśnie w ten sposób nie określit ${ }^{13}$.

\section{Gnój ezystencjalny}

Gnój Wojciecha Kuczoka i Bidul Mariusza Maślanki to książi o bezsilności, przennocy, chorej obyczajowości i patologii.

Stary K. - ojciec glównego bohatera w powieści laureata Nagrody Nike za rok 20)4 czerpie przyjemność z bicia swojego syna pejczem. Najczęściej bez powodu, najczęściej bez opanniçtania.

A potem bral pejcz i bil, zadając pytanie przygotowane specjalnie na okoliczność towarzystwa osób trzecich, to niejako bardzicj sprecyzowane, lecz tez z góry zwalniające muie od wielowyrazowych odpowiedzi. Pytał: Wiesz za co? (cios) - Wiesz za co? (cios) - Wiesz? - (cios) - Wiesz? - (cios) - Wiesz za co? - (cios). W tym wypadku wystarczało mi z calą kategoryczulą pewnością wlasnej niewiedzy odwrzaskiwać . Nie!!” Potem wracal do znajomego i mówil, delikatniutko zdyszany: Co za histeryk pieprzony. Cała matka. Parę klapsów dostaje i ryczy, jakby go zarzynali. I wracal do rozmowy, w której nikt juz num nie przeszkadzał. Aż do konica ((;, 68).

Skandaliczne zachowanie ojca nie umniejsza jego pozycji w rodzinie. Patrialchalny ukfad zostaje zachowany. Protesty matki niewiele pomagają. Prowadzą raczej do awantur i wyzwisk. A Stary K. nie dobiera ani słów, ani narzędzi kar.

Czemuś go zbil?! - pytała matka, z czasem coraz głośniej, czas dodawal jej odwagi, lecz ujmowat nadziei, tote $\dot{z}$ beznadziejność biorąc za podstawowy doping, z czasem pytała coraz wyraźniej, juz bez lez przełykanych, już bez drżenia w głosie, z przcbiśniegani przekleństw. (...) Stary K. odbierał jej język, z ust wyjmował i matka pozostawała bez języka, czy raczej z językiem martwym, zuicczulonym $(G, 88)$.

W innym micjscu czytamy:

No juz, już zaraz pójdzie stąd ten sadysta, więcej cię z nim nie zostawię, jemu to tylko bat dać, żeby ćwiczyl w cyrku zwierzęta, to nie jest normalny chłop, biedne dziecko, Jezus, ty całą szyję masz czerwoną... Czemu on ma znowu szyję 
czerwoną, dusiłeś go, do cholery jasnej, czy co?! Chłopie, z tobą nie można dziecka zostawić na chwilę, przecież ty się nie nadajesz w ogóle na ojca, idź sobie na dół potresować swoje rodzeństwo, ty stary capie sadystyczny!! $(G, 88)$

"Sadystyczny cap” to wytwór naszego dziedzictwa, układów rodzinnych starannie pielęgnowanych (co zresztąjest w tej powieści podkreślane niejednokrotnie). Relacje rodzinne są martwe. Zastępuje je przenoc i brak zrozumienia. Tolerancja staje się pustym stowem. Poszanowanie drugiego czlowieka, partnera i poszanowanie praw dziecka to abstrakcja.

Izolowane wspólnoty ludzkie (rodzina starego K.) opierają się na autorytarnych zależnościach, w których wiçź wspólna jest bardzo silna, a respektowanie i strzeżenie norm regulujących życie wspólnoty tę więź cementuje. Stąd skandal, będący aktem sprzeniewierzającym się normie społecznej, jest też zagrożeniem autorytarnych relacji zankniętych w zbiorowościach, aczkolwiek, co paradoksalne, te autorytatywne więzi potęguje. Albowiem każda próba zlamania jakiegoś elementu struktury danej społeczności jest zarazem czynnikiem mobilizującym, elektryzującym poszczególne jednostki ${ }^{1+}$.

Zachowanie starego K. to już nie tylko skandal, lecz głçboka patologia, która tak zakorzenila się w codzienności, że stała normą. Niereformowalność jego postawy i głębokie przeświadczenie, że tylko strach może wychować syna, jest paradoksalnym odwróceniem naszej poprawności w oczach innych, naszej maski, którą zakładamy codziennie, by obcy mogli wypowiadać się o nas pozytywnie.

Doświadczanie przemocy utwierdza bohatera w przekonaniu, że chciałby zabić ojca. Czeka na ten moment, kiedy go nie będzie. W ostatnicj scenie, gdy wielopokoleniowy dom, z tak zwanymi tradycjami - siedlisko historii, legend, bólı, zla i skandali, zawala się, bohater szuka wzrokiem zwłok ojca. Tymczasem

...ze starego K. pozostała tylko glowa, tylko wyraz twarzy, którym żegnał się ze światem. Wyraz zdumienia, że zbawienie tak boli; zapis tych ulamków sekund, w których pojął, że piekło to nie imni, ze owszem: i sąd i ostateczność tu i teraz - ale dla niego osobiście; ulanków sekund, w których przestawał myśléc o kolejnych zniszczeniach, obliczać listę strat, w których pojąl, że już niczego nie da się naprawić, że to juz: (...) Miał delikatnie zdumione rozwarte usta, teraz wypetnione gliną nie do wyplucia $(\mathrm{G}, 210)$.

Zdziwienie, że jego siła i apodyktyczność przestała panować. Zdziwienie, że, po Miłoszowsku rzecz ujimując, ,innego końca świata nie będzie”.

W Bidulı Mariusz Maślanka obıaża stereotypy i patologie wiejskiej rodziny, która oddajı swoje dzieci do domu dziecka. Główny bohater — dziesięcioletni Borys - jest świadkiem wie luokropności. Otaczający go świat jest wynaturzony. Zlo staje się normą. Skandal — terapią. 
W relacji chłopca pozorny spokój miesza się z bezbrzeżną samotnością, a wynaturzenie zamienia się w normę moralną. Najmłodszego z rodzcństwa Kubę zabiera pogotowie, bo całymi dniami płacze. Rodzice nie karmili go, więc zjadal swoje odchody. To dewiacja czy skandal? Codzienność wielı polskich rodzin czy przyklad jednostkowej patologii? Relatywizm moralny czy rozchwiana norma?

Wyjazd do domu dziecka relacjonowany jest jak weekendowa wycieczka z pogadanką terapentyczną.

Ponad miesiąc temu tato powiedzial nam, że będzic nas musial oddać do domu dziecka. Wtedy spytatem się go: „Co to jest dom dziecka”? A on odpowiedział, że mieszka tam duzo dzieci, a może mało, i my będziemy mieszkać tam razem z nimi, a on czasem będzie nas odwiedzał. (...) Mama dodała, że wreszcie będzie miała od nas święty spokój i w końcu sobie od nas odpocznie, a nuy przynajmniej będziemy mieli co jeść, bo ojciec przepija wszystkie pieniądze $(\mathrm{B}, 9)$.

Ojciec zostawia dzieci w pogotowiu opiekuńczym, ,bo musi jeszcze iść do pracy na drug̨ zmianę" (B, 14). To być może dla nich chwila ocalenia. Trudna do zdefiniowania. Tu jest jedzenic i czyste ubrania. Jest ciepło.

Rodzinne relacje nie istnieją. Przemoc, gwałt, poniżenie, bezsilność i agresja to codzienność wielodzietnej wiejskicj rodziny. Matka nawet się cieszy, że dzieci znikną z domu:

Mama mówiła tym babon, żeby nas wzięly do domu dziecka, bo ojciec nas tyle naruchal i przepija pieniądze, które zarobi, a ona jest chora i musi się leczyć w psychiatryku i nie ma juz do mas sily i nie ma takze sily do pracy, a tam w domu dziecka, będziemy mieć na pewno lepiej, a ona sobie odpocznie $(B, 10)$.

Zresztą, cóz to za dom, w którym alkohol miesza się z wynaturzeniami, przemoc z bólem fizycznym i psychicznym.

... Tato akurat nie naprany w trzy dupy, powiedzial jej żeby przestata pierdolić, bo ją znow'u zamknie w wariatkowie lub jej zaraz przypierdoli. Potem juz było jak zwykle. Po chwili dodawal, żeby się umyla, bo śmierdzi, a on nie będzie wkladał jej swojego fiuta w śmierdząca pizdę. Mama odpowiadała, że i tak ja gwakci po pijanemu i że jego pijacki kutas równieź śmierdzi. Ojcu wówczas piana szła z pyska, więc się dalej kłócili, wyzywali i często rzucali w siebie tym, co mieli pod ręką: łyżką, widelcem, talerzem, kubkiem, stolkiem, drewnem, młotkiem. Te kłótnie i walki wygrywał tato, a mama zaplakana i zakrwawiona wybiegała z domı. Po kilku godzinach wracała i ojciec dalej ją prat $(B, 10)$.

Gnój to rodzinne piekto, w którym dziecko próbuje zachować resztki godności i dumy. Niosąc bagaż trudnych doświadczeń, postanawia wylączyć świadomość i ułożyć sobie życie poza ewokowaniem skandalicznego zachowania ojca. 
Uciekatem od tego domu. Uciekałem z pięściami w kieszeni, uciekalem z obrączkami na palcach, uciekałem z dziećmi na rękach (...) Uciekałem we wszystkie strony jednocześnie. I wszędzie tam, dokąd dotarłem, ciągnąłem za sobą cień tego domu, im dalej uciekalem, tym bardziej się naprężał, krępowal mi ruchy, spowalnial kroki $(\mathrm{G}, 212)$.

Ucieczka ostateczna, oderwanie calkowite nie jest możliwe:

...a nim uległem ostatecznie, zdążyłem stracić mowę (G, 212).

Język nie wyrazi wszystkiego. A więc mowa staje się zbyteczna.

Tytułowy Bidul to spotęgowane piekło. Świat wynaturzeń. Skandal to eufemizm. W listach do Pana Nikt, wrzucanych do kosza na śmieci, Borys opowiada najtragiczniejsze, tym bardziej, ze będące codziennością, wydarzenia.

Kiedy przywiózl nas tu tato z brzydkich stów znałem kurwa i cipa i pizda i chuj i kutas i dziwka i skurwysyn i spierdalaj i pierdol się, a teraz znam ich więcej i mogę ich używać kiedy wyzywam się z chlopakami $(\mathrm{B}, 36)$.

Nietrudno się domyśleć, że wszystkie z nich wypowiadane były w domu podczas pijackich awantur.

Lata 9(). to „oblędny apetyt nil atrakcje”.

Mnóstwo pary poszlo w gwizdek, bo też, z niejasnych do końca powodów, potrzebne bylo przekonanie, że to, co dzieje się w domenie prozy, ma wymiar zjawiskowy i zgola sensacyjny ${ }^{15}$.

Może więc czas, by przywolać pojęcie „skandalı wykreowanego” (termin Piotra Michalowskiego) i odnieść je do Kabaretu metafizycznego, Scen z zycia pozamatżénskiego, Bidula czy tomu opowiadań Przez rzekę. Posądzona o jednostronność osądu, określę jednak skandal we wspólczesnej prozie jako zjawisko artystyczno-pornograficzne. Fakt, który pokazuje, że nie ma już tematów tabu, ze reality shou' dotarlo także do literatury, że nie ma norm, których nie można podważyć. Skandal stał się formą autoprezentacji wspólczesnych twórców. Kryteria estetyczne, etyczne i psychologiczne juz nie wystarczaja w procesie interpretacji. Sensacja przerodziła się niepostrzeżenie w skandal, a potem w patologię. Wypowiedź moja ma więc charakter fragmentaryczny. Teksty poddane analizie to czubek góry lodowej. Jednoznacznt natomiast jest to, że ewolucja kategorii skandalu w prozie najnowszej nie zakończy się na opi. sie patologii. Bo dewiacje się mutują.

Pozostaje tylko kwestia opisu i doboru słów. Język okazuje się po raz kolejny niewystar czającym tworzywem, by oddać świat wynaturzeń. Jak przekazać molestowanie seksualne z punktu przyjemności gwalciciela czy tragedii dziecka? jak opisać seksoholizm — poprzez fi 
zjologię czy cielesność? jak wreszcie przyznać otwarcie, że skandal jest nie jest czymś wyjątkowym, a jedynie otoczką brutalności i zla? Jedna z relacji bohatera Bidula, który wraz z kolegami jest świadkiem przemocy na tle scksualnym, powinna zakończyć dyskusje o skandalu i tym, co etyczne, a co marginalne. Granice już dawno przestały istnieć. Pozostaje interpretacja.

Tymczasem Pyton zdejmuje spodnie i majtki i moim oczom ukazuje się jego futt, który jest wokól obrośnięty czarnymi włosami. Ruszaj - mówi Pyton do Landrynka. (...) Nie, Pyton! - pochlipuje Landrynek - Nie będę! (...) Kurwa ruszaj skórą! - Pyton łapie Landrynka za szyję i przyciąga do siebie, po czym bierze swojego fiuta $w$ dwa palce i chlasta nim Landrynka po twarzy. Landrynek, patrząc Pytonowi w oczy, bierze jego fiuta do ręki. (...) Fiut Pytona robi siç coraz większy, jakby pęczniał. (...) Szybciej i energiczniej! — mówi Pyton, bo ci przyjebię. Poprzednim razem robileś to lepiej. (...) Teraz do buzi mówi Pyton. Landrynek, głęboko patrząc Pytonowi w oczy, dotyka jego fiuta swoimi ustami, po czym całuje i powoli whlada go sobie do buzi. (...) Pyton zaczyna jęczeć (B, 26, 27).

Czy w świetle tych słów skandalem są dwie lechtaczki Beby Mazeppo? 